\title{
The efficacy of Trichoderma spp. and Bacillus isolates in the control of chickpea wilt pathogens
}

\author{
Hanan Ibrahim Mudawi ${ }^{1, ~ *, ~ M o h a m e d ~ O s m a n ~ I d r i s ~}{ }^{2}$ \\ ${ }^{1}$ The Environmental, Natural Resources and Desertification Research Institute, National Centre for Research, Ministry of Science and \\ Technology, Khartoum, Sudan \\ ${ }^{2}$ Department of Plant Protection, College of Agriculture, Khartoum University, Khartoum, Sudan
}

Email address:

hananmodawi@gmail.com (H. I. Mudawi), shid_agic@hotmail.com (I. O. Mohamed)

\section{To cite this article:}

Hanan Ibrahim Mudawi, Mohamed Osman Idris. The Efficacy of Trichoderma spp. and Bacillus Isolates in the Control of Chickpea Wilt Pathogens. Agriculture, Forestry and Fisheries. Vol. 3, No. 5, 2014, pp. 346-351. doi: 10.11648/j.aff.20140305.13

\begin{abstract}
Dual experiments were carried out in 2007 at the laboratories of the National Center of Research, to test the antagonistic efficacy of three Trichoderma spp and 23 Bacillus isolates, for the control of chickpea wilt and root- rot pathogens: Fusarium oxysporum $f$. sp. ciceris and $F$. solani adopting CRD. Trichoderma harzianum was found highly antagonistic compared to Trichoderma viride isolates as it inhibited the mycelial growth of $F$. oxysporum $f$. sp. ciceris and $F$. solani by $85.29 \%$ and $86.21 \%$ after 12 days of in-vitro incubation, whereas T. viride (isolate Tv1) gave an inhibition percentage of $81.88 \%$ and $76.64 \%$. Antagonistic hyphae of $T$. harzianum showed parasitic behavior against Fusarium spp. The parasite reached and recognized $F$. oxysporum f. sp. ciceris by coiling around the hyphae of the pathogen and disintegrating the hyphae and spores. Only 17 out of 23 Bacillus isolates from 130 colonies of bacteria screened showed significantly antagonistic properties against wilt pathogens. Only B3, B16, B2, B15and B20 proved to be the most effective among the rest of isolates and were considered strongly antagonistic against $F$. oxysporum $f$. sp. ciceris and $F$. solani in-vitro, with an inhibition percentage range of $57.57 \%-64.65 \%$. The management of Chickpea root/rot wilt complex disease incited by F. oxysporum $f$. sp. ciceris and $F$. solani could be achieved successively by the use of bioagents derived from various fungal and bacterial isolates.
\end{abstract}

Keywords: Antagonisms, Bacillus spp, Biocontrol, Cicer arietinum L, Trichoderma harzianum, T. viride

\section{Introduction}

Chickpea, Cicer arietinum L., is one of the best legumes for human consumption and widely grown in Northern Sudan. Fusarium oxysporum $f$. sp. ciceris and F. solani are the wilt and root- rot pathogens causing severe damage wherever this crop is grown $[1,2]$.The use of bioagents in the control of pests is a result of the change in the public attitude towards the use of chemical pesticides and fumigates [3]. In this respect, Trichoderma spp. has been studied as biological control agents against soil-borne plant pathogenic fungi and nematodes. They have been investigated for over 80 years and recently used as biological control agents and their isolates have become commercially available. The mechanisms suggested to be involved in their bio-control are antibiosis, lysis, competition, mycoparasitism and promotion of plant growth [4].

Plant growth promotion by Plant Growth Promoting Rhizobacteria (PGPR) may also be an indirect mechanism of biological control, leading to disease escape when the growth promotion results in shortening the time that a plant is in a susceptible state [5]. It was originally reasoned that endophytic bacteria which could colonize vascular tissues of plants would be potential antagonists of vascular-invading pathogens, such as F. oxysporum and Verticillium spp. [6]. One of the advantages of using entophytes is that, once inside the host, they are better protected against environmental stress and microbial competition [7]. Strains of Bacillus are among the most common bacteria found to colonies plants endophytically and are plant growth promoters [8]. Bacillus spp. has the characteristics of being widely distributed in soils, having high thermal tolerance, showing rapid growth in liquid culture, and readily form resistant spores. Abeysinghe [9] screened four isolated rhizobacteria in dual Petri dishes assay as antagonistic against $F$. solani f.sp. phaseoli and reported that Bacillus subtilis CA32 effectively antagonized the pathogen growth by $55.05 \%$ mycelium inhibition mean. Harlapur et al.[10] evaluated eight bio-agents under in-vitro conditions against Exserohilum turcicum, that affect maize 
leaf, and among the bio-agents tested $T$. harzianum caused significantly maximum inhibition $(65.17 \%)$ followed by $T$. viride $(56.95 \%)$ and $B$. subtilis $(49.57 \%)$, while Pseudomonas fluorescens was found to be the least effective (19.30\%).

The objective of this study is to test the antagonistic ability of three Trichoderma spp and two Bacillus isolates obtained from chickpea growing areas at Northern Sudan against $F$. oxysporum $f$. sp. ciceris and $F$. solani the causal agents of wilt root rot disease complex. This disease is highly sever at chickpea grown areas, that leads the farmers to alter the crop with other profitable alternative crops. The morphological antagonistic behaviour of Trichoderma spp in- vitro were also observed.

\section{Materials and Methods}

\subsection{Source of Pathogens}

Soil samples were randomly collected at March 2007 from the rhizosphere of chickpea grown on a sick plot at Shambat Research Station Farm (ARC), heavily infected with wilt/ root-rot disease complex incited by Fusarium spp and the lesion nematode Pratylenchus spp. The sick plot is repeatedly used for chickpea Fusarium wilt resistance screening experiments. The soil was maintained in paper bags and left to dry at room temperature $\left(25-30^{\circ} \mathrm{C}\right)$.

\subsection{Isolation and Identification of Fusarium spp}

Fusarium spp were isolated from air-dried soil samples following the dilution plate method [11]. The samples were thoroughly mixed, and a suspension of $1 \mathrm{~g}$ (dry weight equivalent) in $9 \mathrm{ml}$ of sterilized distilled water was prepared from each sub-sample. A serial dilution of the soil suspensions was prepared (ten-folds), and inoculated on a Fusarium selective Spezieller Nährstoffarmer Agar media (SNA) that composed of KH2PO4 $1.00 \mathrm{~g}$, KNO3 $1.00 \mathrm{~g}$, $\mathrm{MgSO} 4.7 \mathrm{H} 2 \mathrm{O} 0.50 \mathrm{~g}, \mathrm{KCl} 0.50 \mathrm{~g}$, Glucose $0.20 \mathrm{~g}$, Sucrose $0.20 \mathrm{~g}$, Agar $20.00 \mathrm{~g}$, Distilled water $1.00 \mathrm{~L}$, supplemented with $0.05 \mathrm{~g}$ chloramphenicol as anti-bacterial. And 1-2 pieces of sterile filter paper (Whatman № 1) were placed, approximately $1 \mathrm{~cm}^{2}$ on the agar surface to enhance sporulation. The media were allowed to dry for 3 days [15]. Individual colonies resembling Fusarium spp were transferred to Potato Dextrose Agar (PDA) media (Unpeeled potato $200 \mathrm{~g}$, Dextrose $20 \mathrm{~g}$, Agar 20g, Distilled water $1 \mathrm{~L}$ ) and incubated for $10-15$ days at $25^{\circ} \mathrm{C}$ in the dark. Production of pigmentation was observed on SNA media. The isolates were maintained on sterilized soil-agar at $4^{\circ} \mathrm{C}$ and / or PDA medium at $25^{\circ} \mathrm{C}$ and sub-cultured every three months. Identification of isolates was based on cultural, microscopic characteristics with reference to Leslie and Summerell's Fusarium laboratory manual [12].

\subsection{Isolation of Antagonistic Bacteria (SciencePG-Level3-Multiple-Line)}

Twenty- three bacteria isolates were used in this study.
Thirteen strains were isolated from the rhizosphere of the main chickpea growing areas of Adu Hamad (northern Sudan). Eight grams of soil samples were transferred to a $100 \mathrm{ml}$ beaker and filled with $40 \mathrm{ml}$ of sterilized water. The beaker was heated in a water path for 10 minutes at approximately $80^{\circ} \mathrm{C}$ and agitated during the process. The soil suspension was serially diluted, spread on Nutrient Agar (NA), on Petri plates using a spreader and inoculated at $28^{\circ} \mathrm{C}$ for $48 \mathrm{~h}$. Five replicated plates were prepared for each dilution $\left(1 \times 10^{5}\right.$ and $\left.1 \times 10^{7}\right)$. Colonies were isolated on the basis of their different visual characteristics. After isolation, all colonies were purified by single colony isolation after triple re-streaking on NA medium. Colonies morphologically resembling Bacillus species were subcultured and maintained on NA tubes according to Claus and Berkeley [13]. The bacterial isolates were stored in NA tubes at $4^{\circ} \mathrm{C}$ and sub-cultured every three months. Active cultures were prepared in NA tubes $48 \mathrm{~h}$ before application.

\subsection{Isolation of Trichoderma spp and Inoculum Preparation}

The fungal antagonists were isolated from soil samples brought from Shambat area (Central Sudan), using dilution plate techniques [11] on Trichoderma selective medium, cultures were incubated for 2 days on SNA medium in the dark, followed by incubation under ambient laboratory conditions of light and temperature (about $23^{\circ} \mathrm{C}$ ). After an incubation period, colonies determined to be Trichoderma spp., were purified and identified on the basis of their morphological characters [14]. Trichoderma spp. were maintained on PDA media and stored at $4{ }^{\circ} \mathrm{C}$. Two isolates were isolated and identified in this study Trichoderma harzianum (Ts) and T. viride (Tv1), the other isolate were obtained from Khartoum Crop Protection Department (isolated from northern Sudan soil) and were identified as $T$. viride (Tv2).

The inocula of Trichoderma spp were prepared from $8-10$ days old culture grown on PDA media. Ten (10) $\mathrm{ml}$ of sterilized distilled water were added to each Petri dish, and the surface of the culture was scraped with a glass spatula to dislodge the spores. The spore suspension derived from six Petri dishes was transferred to $100 \mathrm{ml}$ sterilized flask. One ml of each isolate was poured into PDA Petri dishes, allowed to dry for 3 days, and incubated at room temperature for one day.

\subsection{In-Vitro Antagonistic Tests}

The in-vitro antagonistic properties of bacteria isolates and Trichoderma spp were investigated against Fusarium spp. Assay were performed in Petri plates $(90 \mathrm{~mm})$ containing 20 $\mathrm{ml}$ of PDA, allowed to dry for 3 days. An entire pure culture, 4 $\mathrm{mm}$ in diameter obtained from one day old Trichoderma $\mathrm{spp}$ and 7-10 days old cultures of $F$. oxysporum $f$. sp. ciceris and F.solani were cut using a cork-borer. Pathogens disks were transferred $10 \mathrm{~mm}$ from the edge of each Petri dish. Each Trichoderma spp was placed $10 \mathrm{~mm}$ from the other edge, opposite to the pathogens. The inoculated plates were then incubated upside-down at $25^{\circ} \mathrm{C}$, and were observed for 
inhibition or otherwise of their growth for 12 days. Each bacterial isolate were spotted with a sterile tooth- stick (four spots per plate), $10 \mathrm{~mm}$ from the opposite edge of the Petri dish and opposite to the pathogens [15] and were observed for inhibition for 7 days. The control Petri dishes were inoculated each alone with F. oxysporum $f$. sp. ciceris and F.solani. The radial growth of the two pathogens in the control and the treated Petri dishes were measured every $24 \mathrm{~h}$, and the inhibition percentage of the antagonism was calculated according to the following formula:

The percentage inhibition $=\mathrm{R} 1-\mathrm{R} 2 / \mathrm{R} 1 \times 100$

Where $\mathrm{R} 1$ is the value of radial growth of pathogen in control plates and R2 is the radial growth of the pathogen in the treated plates [16].

\subsection{Analysis of Data}

A completely randomized design (CRD) with five replicates for the effect of Trichoderma spp and three replicates for bacterial effect was adopted in this part of the study. The percentage of inhibition was arc sin transformed and the data means were analyzed according to Duncan multiple range test at $P \leq 0.05$ to test significant differences between treatments [17].

\section{Results}

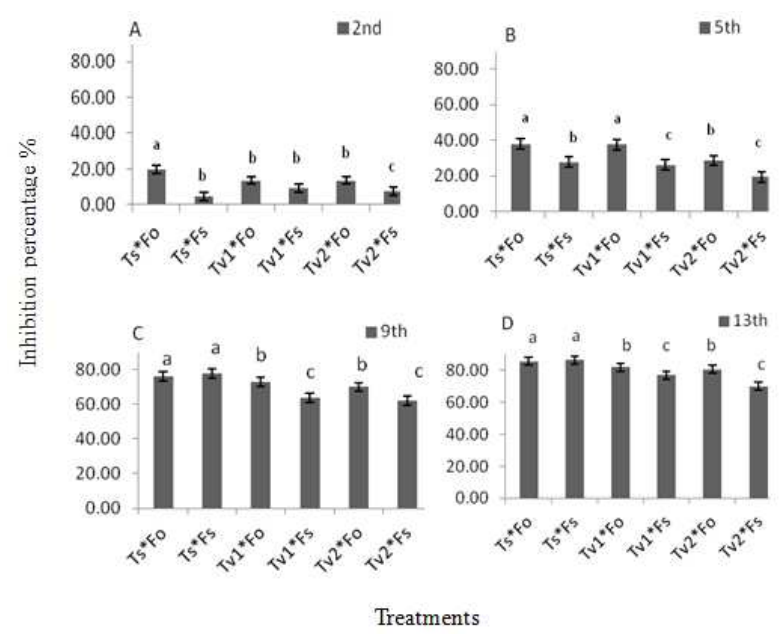

Figure 1. Mean inhibition percentages of the radial growth of F. oxysporum f.sp. ciceris and F.solani treated with three Trichoderma isolates on PDA media from the 2 nd day after inoculation. .Vertical bars represent standard errors. Bars with the same letter are not significantly different at $P \leq 0.05$.

Using the serial dilution isolation technique described above, thirteen isolates were preliminary characterized as member of the genus Bacillus based on its colony morphology, gram-positive reaction, spore forming and the presence of the bacillus-shape under the electron microscope [13]. The fungi isolated from the sick plot (Shambat Research Station Farm) were identified as F. oxysporum f. sp. ciceris and F. solani according to Leslie and Summerell's Fusarium laboratory manual [12]. Whereas three species of Trichoderma were isolated from Shambat area (Central Sudan), one isolate was identified as T. harzianum (Ts), and two were identified as T.viride (Tv1 and Tv2) according to [14]

Antagonistic properties of T.viride (Tv1 and Tv2) and $T$. harzianum (Ts) were tested against the $F$. oxysporum $f$. sp. ciceris and $F$. solani, using dual Petri plate method. It appeared from the data presented in Figure 1 that all the antagonistic fungi significantly $(P \leq 0.05)$ inhibited the growth of $F$. oxysporum $f$. sp. ciceris and F.solani against the control plates during all days of treatments. T. harzianum were found significantly superior in antagonizing the two pathogens than $T$. viride isolates, inhibiting the mycelial growth of F.oxysporum $f$. sp. ciceris and $F$. solani with a range of $19.78 \%$ to $85.29 \%$ and $4.52 \%$ to $86.21 \%$ respectively during the incubation days (Fig.1) with no significant difference at the13th day after inoculation. The effect of T.harzianum was highly superior from the second day of inoculation recording an inhibition percentage of $19.78 \%$ in comparison with the other species. After 5 days of inoculation, T. harzianum resulted in inhibiting the two pathogens by $37.93 \%, 75.90 \%$, $85.29 \%$ and $27.83 \%, 77.70 \%, 86.21 \%$ during the $5^{\text {th }}, 9^{\text {th }}$ and $13^{\text {th }}$ days after inoculation; respectively (Fig.1.A, B, C).

T. viride isolates (Tv1 and Tv2) gave an inhibition percentage of $37.62 \%, 28.67 \%$ and $26.17 \%, 19.52 \%$ after 5 days; respectively (Fig.1A) and $72.79 \%, 69.84 \%$ and $63.42 \%$, $61.80 \%$ after the $9^{\text {th }}$ day; respectively (Fig.1B) and $81.88 \%$, $80.29 \%$ and $76.64 \%, 69.67 \%$ after the $13^{\text {th }}$ day after inoculation; respectively (Fig.1C).
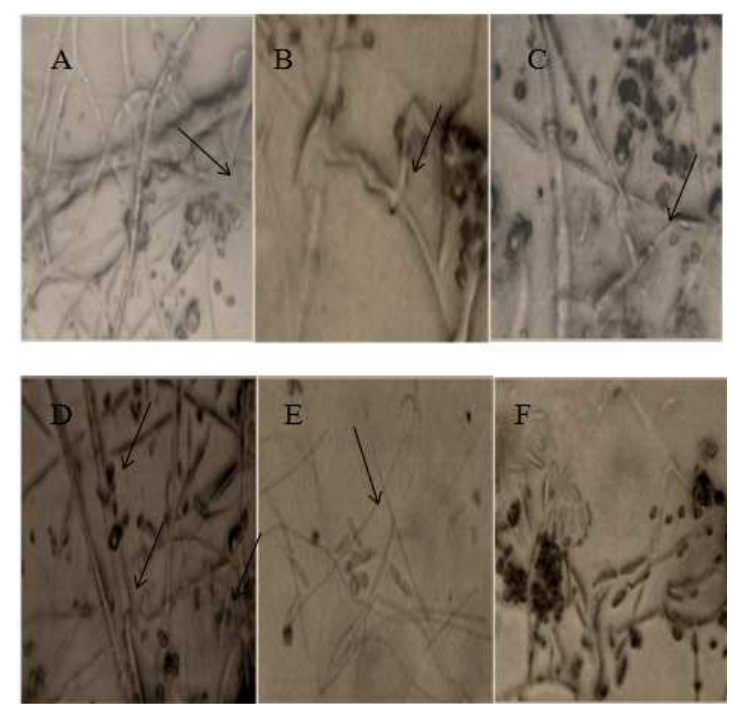

Figure 2. (A) The parasitic hyphae of $T$. harzianum reached and recognized the host hyphae Foxysporum f.sp. ciceris (B) coiling, (C) encircling, (D) penetrating the mycelia and disintegrating the hyphal cell wall, (E) Normal septation of F.oxysporum f.sp. ciceris spores, $(F)$ invaded and disintegrated spores by T. harzianum with no or faint septation as shown by the arrows.

From day five onward, the inhibition percentage of the mycelial growth of pathogens by Trichoderma isolates increased (Fig.1). From day 9 to the end of the experiment F.oxysporum $f$. sp. ciceris and $F$. solani were more sensitive. T. viride isolates were never observed to overgrow the tested fungus. Among the two T. viride isolates isolate Tv1 was significantly $(P \leq 0.05)$ more effective in inhibiting the 
mycelial growth of the two pathogens.

Observations of hyphal interaction indicated that antagonistic hyphae of $T$. harzianum showing parasitic behavior against Fusarium spp. The parasite reached and recognized the pathogen (Fig. 2A), by coiling around the hyphae of pathogen and disintegrating them (Fig. 2B and C). Occasionally T. harzianum hyphae formed a hook or bunch like structures around the hyphae of the pathogen from where penetration took place (Fig. 2C and D). Hyphae of antagonist either coiled around the hyphae of $F$. oxysporum $f$. sp. ciceris before penetration (Fig. 2B) or entered directly without the formation of appressorium-like structures suggesting mechanical activity (Fig. 2D). The host hyphae eventually disintegrated (Fig.2E).The spores of $F$. oxysporum $f$. sp. ciceris was disintegrated shown no or faint septation (Fig. $2 \mathrm{~F}$ ). The antagonistic mycelium of T. harzianum overgrew on the mycelium of F. oxysporum f. sp. ciceris after day 10, whereas $T$. viride isolates only arrested the mycelium growth of F.solani.

Twenty three bacterial isolates were tested in- vitro, out of 130 colonies isolated from the infected soil, for inhibition of mycelium growth of F.oxysporum f.sp. ciceris and F. solani (Fig. 3). Sixteen isolates suppressed mycelium growth of F.oxysporum f.sp ciceris but nine isolates, B3, B16, B2, B15, $\mathrm{B} 22, \mathrm{~B} 20, \mathrm{~B} 11$ and $\mathrm{B} 18$ were significantly $(P \leq 0.05)$ superior to the rest of isolates (Fig. 3A), with an inhibition percentage of $64.65 \%, 63.95 \%, 62.60 \%, 62.60 \%, 58.22 \%, 57.57 \%$ $51.64 \%$, and $50.96 \%$, respectively. Also the mycelial growth of $F$. solani was significantly $(P \leq 0.05)$ suppressed by nine isolates, B3, B4, B6, B10, B11, B14, B16, B19, and B22, but the most effective isolates were B16, B3 and B22 (Fig. 3B) with an inhibition percentage of 55.76\%, 51.06\% and $49.17 \%$ respectively.

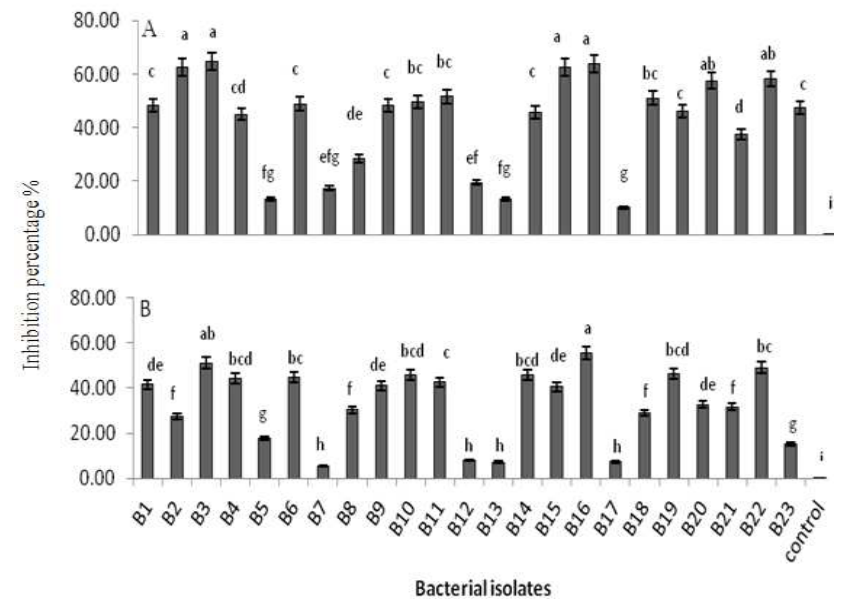

Figure 3. Mean inhibition percentage of (A). F.oxysporum f.sp. ciceris and (B). F.solani treated with 23 bacterial isolates on PDA media after 7 days of inoculation. Vertical bars represent standard error from the means. Bars with the same letter are not significantly different at $P \leq 0.05$.

These three isolates were considered highly inhibitory against the two pathogens. F.oxysporum f.sp ciceris was more sensitive to bacterial isolate than $F$. solani evidenced by the inhibition percentages recorded "Fig. 3". However, for the rest of the bacterial isolates, F.oxysporum f.sp ciceris and $F$. solani over grew the bacterial isolates. In the control treatments the phytopathogens completely covered the Petri dishes.

\section{Discussion}

The results obtained suggested that Trichoderma spp. is capable of producing a range of metabolites, which have antifungal activity. T. harzianum and T. viride significantly $(P \leq 0.05)$ inhibited the growth of fungal pathogens and reduce the mycelial growth indicating antagonistic properties against the pathogens. Somasekhara et al. [18] reported that bioagents such as T. viride, T. harzianum and T. hamatum are effective in controlling pigeonpea wilt caused by $F$. oxysporum $f$. sp. udum.

The minimum growth inhibition percentages of Fusarium spps ( $8.45 \%-34.43 \%)$, incited by Trichoderma isolates were at 4 and 5 days after incubation. This may be due to high pathogenic virulence of the pathogens, which resisted the inhibitory action of Trichoderma species. From day 6 a gradual increase in the inhibition action was recorded, attaining its maximum of $86.21 \%$ at day 13 after inoculation. Overgrowing behaviour of the pathogen was observed when $F$. oxysporum f.sp. ciceris was treated with $T$. harzianum. The Trichoderma spps used in this study were found more aggressive antagonisms than that used by Nikam et al. [19] who reported that $T$. harzianum was more effective in inhibiting the mycelial growth of $F$. oxysporum f.sp. ciceris by $83.33 \%$ than $T$. viride (76.66\%). Production of chitinolytic and glucanolytic enzymes from $T$. harzianum may have direct significance in the parasitism on F. oxysporum f.sp. ciceris as these enzymes function by breaking down the polysaccharides, chitin and $\beta$-glucan that are responsible for the rigidity of fungal cell walls and interact synergistically to achieve a high level of antifungal activity, thereby destroying cell wall integrity, which could explain the strong antagonistic results of T. harzianum [20,21].

It was observed that the antagonisms were expressed as arresting the mycelium growth of F.solani. One of possible mechanisms is fungistasis, in which inhibition of germination has been considered a survival mechanism which arrest fungal growth and biologically controls the pathogenic fungi [22]. There could be other reasons for this result; for instance, the increase was favored through antibiotic production by the mature mycelium. Such antibiotics had indeed been reported by workers like Jayaswal et al. [23], Mcloughlin et al. [24] and Montealegre et al. [25] who reported that Trichoderma spp. secreted chitinase and B-1, 3 glucanase in supernatants.

The in vitro culture of Fusarium spp and Trichoderma spp in culture media led to a variety of interactions. Fusarium spp growth was generally inhibited; the host cell contents disorganized and the hyphae were intensively parasitized by Trichoderma spp. similar reactions have been reported on other fungal pathogens [26].

Mycoparasitism behaviour displayed by Trichoderma spp. was evidenced by the microscopic observations of the interaction regions between F.oxysporum f.sp. ciceris and T. 
harzianum. The mycelia of T. harzianum grew on the surface of the pathogen always coil round their mycelia and later penetrate their cell walls directly without formation of appressorium structures. The mycelia of the pathogen then disintegrate suggesting an enzyme action [27, 28]. Lorito et al. [20], Metcalf and Wilson [29] and Sharon et al. [30], demonstrated the possible role of chitinolytic and/or glucanases enzymes in the biocontrol exhibited by Trichoderma. These enzymes function by breaking down the polysaccharides, chitin, and glucans that are responsible for the rigidity of fungal cell walls, thereby destroying cell wall integrity limiting the growth of the pathogen. A mixture of several enzymes might be necessary for efficient cell wall lysis. T. viride and T. harzianum were reported by several workers as the best antagonists for growth inhibition of several soil and seed borne plant pathogens [31, 32].

From the 23 bacterial isolates used, only nine isolates were able to antagonize $F$. oxysporum $f$.sp. ciceris in dual Petri plate assay. Isolate B3, B16, B2, B15, B 22, B20, B11, B18 and B10 significantly inhibit $F$. oxysporum f.sp. ciceris radial growth recording a percentage inhibition range of $64.65 \%-50.96 \%$, on the other hand, only three isolates were highly significantly able to inhibit F.solani percentage radial growth namely B16, B3 and B22, with a percentage inhibition of $55.77 \%, 51.05 \%$ and $49.17 \%$; respectively. These results were in agreement with that reported by Abeysinge [11]. Some bacteria isolates change the media colour especially near the inhibition zone resulting in mycelial growth retardation. This behavior was observed when F. oxysporum f.sp. ciceri was treated with B3 and B16, which assumed to be a result of excretion of inhibitory substances or enzymes. Reduction of fungal growth by certain PGPR and formation of inhibition zones were presumably due to the materials; antifungal substances and/or cell wall degrading enzymes; released by the bacteria into the culture medium [33]. Also, Sarhan et al. [34] and Montealegre et al. [25] pointed that the cell free culture filtrate of $B$. subtilis inhibited the mycelial growth, radial growth, and spore germination and germ-tubes length of $F$. oxysporum f.sp. ciceri. Many strains of Bacillus strains have been found to be potential biocontrol agents against fungal pathogens. This antifungal action involves the production of antibiotics, especially within soil microsites [35]. However, it is likely that several mechanisms act in concert to achieve control, including the production of volatiles, which have a significant effect on soil microbiology, including the soil-borne plant pathogens such as Rhizoctonia solani and Pythium ultimum [36]. The isolates B3 and B16 were the strongest antagonistic isolates against the two pathogens.

The protection exerted by the Trichoderma isolates against the fungal pathogens was pronounced than Bacillus isolates conformed by the high mycelial radius growth inhibition percentages, which confirms the results of Harlapur et al. [10].This difference may be due to more than one mode of mechanisms exerted by the Trichoderma spp which may have an additive effect in plant protection. Moreover, Trichoderma spp is a well-known producer of cell wall-degrading enzymes and antibiotics thus could act synergistically with other mechanisms [37]. F.oxysporum f.sp ciceris was more sensitive against fungal and bacterial antagonisms than $F$. solani evidenced by the inhibition percentages recorded.

In conclusion, the present study clearly demonstrated that antagonistic Bacillus isolates and Trichoderma spp can be used as biological control agents in order to protect chickpea plants from wilt/root-rot pathogens. The combined use of these biocontrol agents and the evaluation of the biological control efficacy under pot trail conditions are underway.

\section{Acknowledgements}

The authors like to express their thanks to Dr Suad Algam at the department of crop protection, Khartoum University for kindly providing ten isolates of Bacillus spp.

\section{References}

[1] R. S. Singh, "Plant diseases, $6^{\text {th }}$ ed., Oxford and IBH Publishing Co. Pvt. Ltd. 1996, pp. 98-102.

[2] P. Castillo, M. P. Mora-Rodríguez, J. A. Navas-Cortés and R. M. Jiménez- Díaz "Interactions of Pratylenchus thornei and Fusarium oxysporum $f$. sp. ciceris on chickpea". Phytopathology, 1998, 88:828-836.

[3] Y. Elad, I. Chet, and J. Katan, "Trichoderma harzianum: a biocontrol agent effective against Sclerotium rolfsii and Rhizoctonia solani," Phytopathology, 70, 1980, pp. 119-121.

[4] L. G. Hjeljord, A. Stensvand, and A. Tronsmo," Antagonism of nutrient-activated conidia of Trichoderma harzianum (atroviride) P1 against Botrytis cinerea," Phytopathology, 91, 2001, pp. 1172-1180.

[5] J. W. Kloepper, R. Rodriguez-Ubana, G. W. Zehnder, J. F. Murphy, E. Sikora, and C. Fernandez, "Plant root-bacterial interactions in biological control of soilborne diseases and potential extension to systemic and foliar diseases" Australasian Plant Pathology , 28, 1999, pp.21-26.

[6] J. Hallmann, A. Quadt-Hallmann, W.F Mahaffee, and J.W. Kloepper," Bacterial endophytes in agricultural crops," Canadian Journal of Microbiology, 43, 1997, 895-914.

[7] R. Law and D.H. Lewis," Biotic environments and maintenance of sex: Some evidence from mutualistic symbioses,” Biological Journal Linnean Society, 20: 1993, pp. 249-276.

[8] W.F. Mahaffee, and J.W. Kloepper, "Temporal changes in the bacterial communities of soil rhizosphere and endorhiza associated with field- grown cucumber (Cumcumis sativus L.)," Microbial Ecology, 34, 1997, pp. 210- 223.

[9] S. Abeysinghe. "Biological control of Fusarium solani f. sp. phaseoli the causal agent of root rot of bean using Bacillus subtilis CA32 and Trichoderma harzianum RU01". Ruhuna Journal of Science. Vol. 2, 2007, pp. 82-88, http://www.ruh.ac.lk/rjs/rjs.html.

[10] S.I.Harlapur, M.S. kulkarni, M.C. Wali, and Srikantkulkarni, "Evaluation of Plant Extracts, Bio-agents and Fungicides against Exserohilum turcicum (Pass.) Leonard and Suggs. Causing Turcicum Leaf Blight of Maize," Karnataka J. Agric. Sci., 20 (3) 2007, pp. 541-544. 
[11] H.W. Seeley, and P.J. Van Demark, Microbes in action. A laboratory manual of Microbiology, $3^{\text {rd }}$ ed., W.H Freeman and Company U.S.A. 1981, pp. 350.

[12] J.F. Leslie and B. A. Summerell, Fusarium laboratory manual, $1^{\text {st }}$ ed., Blackwell Publishing, Asia, 2006, pp. 387.

[13] D. Claus and, R. C. W. Berkeley. "Genus Bacillus," in, Bergey's Manual of Systamic Bacteriology, vol. 2, P. H. A. Sneath, N. S. Mair and, N. S. Sharp, Eds. Williams and Wilkins, Baltimore, MD, 1986. pp. 1105-1139.

[14] W Gams, and J. Bissett, Morphology and identification of Trichoderma. In, Trichoderma and Gliocladium. Basic biology, taxonomy and genetics, vol 1. G. E. Harman, and C. P Kubicek, Eds. Taylor and Francis Ltd, London, 1998, pp. 3-31.

[15] F. Besson, F. Peypoux, G. Michel, and, L. Delcambe. "Identification of antibiotics of iturn group in various strains of Bacillus subtillus". Journal of Antibiotics 1978, 31: 284-288.

[16] A.C. Odebode, "Control of postharvest pathogens of fruits by culture filtrates from antagonistic fungi. Journal of plant protection research, vol. 46, No. 1. 2006

[17] K. A Gomez and A. A. Gomez, Statistical Procedures for Agriculture Research. 2nd ed. Wiley, New York, U.S.A. 1984, pp. 680 .

[18] Y.M. Somasekhara, T.B. Anilkumar, and A.H. Siddarad, "Biocontrol of pigeonpea wilt Fusarium udum," Mysore J. Agric., 30, 1996, pp. 159-163.

[19] P. S. Nikam, G. P. Jagtap, and P. L. Sontakke, "Management of chickpea wilt caused by Fusarium oxysporum $f$. sp. ciceris," African Journal of Agricultural Research, vol. 2 (12), 2007, pp. 692-697.

[20] M. Lorito, SL. Woo, I. Garcia Fernandez, G. Colucci, G.E. Harman, J.A. Pintor-Toro, E. Filippone, S. Mucciflora, C.B. Lawrence, A. Zoina, S. Tuzun, and F. Scala, "Genes from mycoparasitic fungi as a source for improving plant resistance to fungal pathogens," USA Proc. Natl. Acad. Sci., 95, 1998, pp. 7860-7865.

[21] C.R. Howell, "Mechanisms employed by Trichoderma species in the biological control of plant diseases: The history and evolution of current concepts," Plant Disease, 87, 2003, pp. 4-10.

[22] D. Klein, and D.E. Evenigh, "Ecology of Trichoderma," in Trichoderma and Gliocladium. Basic biology, taxonomy and genetics, voll, G. E. Harman; and C. P Kubicek, Eds. Taylor and Francis Ltd, London, 1998, pp. 57- 74.

[23] R. K. Jayaswal, M. A. Fernandez, and, R. O. Schroeder, "Isolation and characterization of a Pseudomonas strain that restricts growth of various phytopathogenic fungi," Appl. Environ. Microbiol., 56, 1990, pp. 1053-1058.

[24] T.J. Mcloughlin, J.P. Quinn, A. Betterman, and R. Bookland, "Pseudomonas cepacia suppression of sunflower wilt fungus and role of antifungal compounds in controlling the disease," Appl. Environ. Microbiol., 58, 1992, pp. 1760-1763.
[25] J.R. Montealegre, R. Herrera, J.C. Velasquez, P. Silva, X. Besoain, and L.M. Perez, "Biocontrol of root and crown rot in tomatoes under greenhouse conditions using Trichoderma harzianum and Paenibacillus lentimorbus. Additional effect of solarization," Electronic Biotech., 8, 2005, pp. 249-257.

[26] L. E Hanson, and, C. R. Howell, "Elicitors of plant defence responses from biocontrol strains of Trichoderma virens". Phytopathology, 94, 2004, pp.171-176.

[27] B. Padmodaya, and H.R. Reddy, "Screening of Trichoderma spp. against Fusarium oxysporum $f$. sp. lycopersici causing wilt in tomato," Indian J. Mycol. Plant Pathol., 26, 1996, pp. 266-270.

[28] D. Kumar, and S.C. Dubey," Management of collar rot of pea by the integration of biological and chemical methods," Indian Phytopath., 57, 2001, pp. 62-66.

[29] D.D. Metcalf, and C.C. Wilson," The process of antagonism of Sclerotium cepivorum in white rot affected onion roots by Trichoderma koningii," Plant Pathol., 50, 2001, pp. 249-257.

[30] E. Sharon, M. Bar-Eyai, I. Chet, A. Hewrra-Estrella, O. Kleifeld, and Y. Spiegal, "Biological control of the rootknot nematode Meloidogyne javanica by Trichoderma harzianum," Phytopathol. 91, 2001, pp. 687-693.

[31] S.C. Dubey, "Integrated management of web blight of mung bean by bio-seed treatment," .Indian Phytopath., 56, 2003, pp. 34-38.

[32] R.K. Poddar, D.V. Singh, and S.C. Dubey, "Integrated application of Trichoderma harzianum mutants and carbendazim to manage chickpea wilt (Fusarium oxysporum $f$. sp. ciceris)," Indian J. Agric. Sci., 74, 2004, pp. 346-348.

[33] F. Zarrin. M. Saleemi, M. Zia, T Sultan, M. Aslam, R, U. Rehman, and M, C. Fayyaz, "Antifungal activity of plant growth-promoting rhizobacteria isolates against Rhizoctonia solani in wheat," African Journal of Biotechnology, vol. 8 (2), 2009, pp. 219-225.

[34] M. M. Sarhan, S.M. Ezzat, A.A. Tohamy, A.A. El-Essawy, and F.A. Mohamed, "Biocontrol of Fusarium tomato wilt diseases by Bacillus subtilis" Egypt. J. Microbiol., 36, 2001, pp. 376-386.

[35] D. R. Fravel, "Commercialization and Implementation of Biocontrol," Annual Review of Phytopathology, 43, 2005, 337-359.

[36] H. Kim, J. Park, S. Choi, K. Choi, G.P. Lee, S. J. Ban, H. C. Lee, and S. C. Kim, Isolation and Characterization of Bacillus Strains for Biological Control," The Journal of Microbiology, vol. 41, no. 3, 2003, pp.196-201.

[37] F. Vinale, K. Sivasithamparam, E. L. Ghisalberti, R. Marra, S. L. Woo, and M. Lorito, "Trichoderma-plant-pathogen interactions. Soil Biology and Biochemistry, 40, 2008, pp. 1-10. http://www.elsevier.com/locate/soilbio. 